\title{
Fish habitat availability simulations using different morphological variables
}

\author{
Isabel Boavida ${ }^{1, *}$, José Maria Santos ${ }^{2}$, António N. Pinheiro ${ }^{1}$ and Maria Teresa Ferreira ${ }^{2}$ \\ ${ }^{1}$ CEHIDRO, Instituto Superior Técnico, Technical University of Lisbon, Av. Rovisco Pais, 1049-001 Lisboa, \\ Portugal Tel.: 218418148 Fax: 218497650. \\ ${ }^{2}$ Centro de Estudos Florestais, Technical University of Lisbon, Tapada da Ajuda, 1349-017 Lisboa, Portugal. \\ * Corresponding author: isabelboavida@ist.utl.pt
}

Received: 23/2/2010 Accepted: 2/12/2010

\begin{abstract}
Fish habitat availability simulations using different morphological variables

Fish habitat modelling results are strongly influenced by velocity and depth patterns as well as by morphological parameters of the riverbed (i.e., substrate and refuge cover). Studies regarding the use of substrate in habitat modelling are well represented in the literature, whereas the use of cover in such models is commonly neglected because it is difficult to quantify the refuges or the instream areas where fish can hide from predators. However, there is clear evidence that fish habitat use and preferences are associated with refuge cover. Ignoring this variable can lead to incorrect restoration and flow management decisions based on misleading results. To avoid this, river restoration goals should only be set with reference to habitat conditions found at undisturbed sites rather than with the aim of improving habitat heterogeneity. The aim of this study is to compare the habitat availability for two cyprinid fishes, the Southwestern arched-mouth nase (Iberochondrostoma almacai) and the Arade chub (Squalius aradensis), at undisturbed (i.e., near-natural state) and disturbed sites (i.e., sites impacted by agricultural activities that have led to nutrient enrichment, destruction of riparian woodlands, straightening of the river channel and water abstraction). This is done by alternately considering substrate or refuge cover in a weighted usable area (WUA) determination to understand the interactive effects of these morphological variables as well as their influence on habitat availability. Different outcomes were generated by the use of refuge cover and substrate in habitat simulation. The results underline the importance of considering refuge cover in habitat models and also point to the need to take into account minimally disturbed or undisturbed sites within the same river upon developing future management actions.
\end{abstract}

Key words: WUA, refuge cover, substrate, habitat heterogeneity, restoration.

\section{RESUMEN}

\section{Simulaciones de disponibilidad de hábitat usando diferentes parámetros morfológicos}

Los resultados de la modelación de hábitats piscícolas están fuertemente influenciados por la velocidad y los patrones de profundidad, así como por los parámetros morfológicos (i.e. substrato y cobertura de refugio) del lecho del río. Estudios sobre el uso de sustrato en la modelización del hábitat están bien descritos en la literatura, mientras que el uso de la cobertura es frecuentemente omitida, ya que es difícil de cuantificar el refugio o las zonas donde los peces se pueden abrigar y ocultar de los predadores. Sin embargo, hay pruebas claras de que el uso y las preferencias de los peces también están asociados con la cobertura de refugio. Ignorando esta variable puede conducir a decisiones de restauración fluvial y de gestión de los recursos hídricos apoyados en resultados engañosos. Para evitar eso, los objetivos de la restauración fluvial se debían establecer con referencia a las condiciones de habitat que se pueden encontrar en trechos de río no alterados, en lugar de mejorar la heterogeneidad del hábitat. El objetivo de este estudio es comparar la disponibilidad de hábitat para dos peces ciprínido, el boga del Sudoeste (Iberochondrostoma almacai) y el cacho del Arade (Squalius aradensis) en trechos de río no perturbados (i.e. próximo del natural) y perturbados (i.e. perturbados por actividades agricolas que llevan a un enriquecimiento de nutrientes, destrucción de la mata riparia, enderezamiento del cauce y abstracción de água). Esto es hecho considerando alternativamente o sustrato o la cobertura de refugio en la determinación del weighted usable area (WUA) a fin de dar a conocer los efectos interactivos de las variables morfológicas, así como su influencia en la disponibilidad de hábitat. Diferentes respuestas fueran encontradas con el uso posterior de la cobertura de refugio y el sustrato en la simulación del 
hábitat. Los resultados exponen la importancia de considerar la cobertura de refugio en los modelos de hábitat y además apuntan la necesidad de tener en cuenta sitios mínimamente alterados o no perturbados de un mismo río para el desarrollo de futuras acciones de gestión fluvial.

Palabras clave: WUA, cobertura de refugio, sustrato, heterogeneidad del hábitat, restauración.

\section{INTRODUCTION}

Rivers are amongst the ecosystems that have been most degraded by human intervention, largely through morphological changes and alterations to flow regime (Naiman \& Turner, 2000; Sala et al., 2000; Gleick, 2003). This has resulted in a loss of habitat complexity due to the elimination of natural mesohabitat sequences, increased uniformity of channel geometry, changes in water temperature regimes, bed erosion and downstream sedimentation (Petts et al., 1989), with obvious negative consequences for many fish populations (Wesche, 1985). Concern about ecological losses has recently stimulated major conservation and management efforts, reflected in the increasing number of articles addressing river restoration and the large amount of money spent on restoration projects (Henry et al., 2002; Wheaton et al., 2004; Woolsey et al., 2007). However, river restoration, defined as the process of returning a river to a near-natural state (Palmer et al., 2005; Roni, 2005), is not always successful; indeed, many attempts at restoration are only modestly successful in improving conditions (Harper et al., 1998; Pretty et al., 2003; Harrison et al., 2004).

To maximise success, river restoration should be set in the context of 'benchmark' conditions describing the dynamic and ecologically healthy river that should exist at a specific site, i.e., those that can be found at relatively undisturbed sites of the same river type (Rheinhardt et al., 1999), rather than attempt to create conditions unrelated to the original ones at the site of interest (Choi, 2004; Palmer et al., 2004; Suding et al., 2004; Woolsey et al., 2007). Nonetheless, many habitat improvement schemes still follow the concept that increasing physical heterogeneity will lead to an increase in biodiversity (Jungwirth et al., 1995; Kondolf \& Micheli, 1995; Montgomery, 1997; Palmer et al., 1997; Kemp et al., 1999), which is not always true. The assumption of these studies is that more complex habitat structure should be the basic aim of habitat improvement.

Although theoretically sound, the 'benchmark' site is not easy to model because natural instream habitats consist of complex multidimensional arrays of morphological conditions such as substrate structure, woody debris and plant growth, which in combination influence the observed hydraulic patterns. Furthermore, the expected 'natural' distribution of fish species should take into account species composition, life stages and habitat guilds to correctly identify the amounts of preferred habitats in a given stream and in which proportions these habitats exist (Strange, 1999). The distribution of each species in the "natural' stream is determined by a multidimensional set of environmental conditions (e.g., velocity, depth, temperature) and resources (e.g., food, space) that support a viable population containing all life stages (Colwell \& Futuyma, 1971; Statzner et al., 1988), and these must be reflected in the restored stream.

Physical heterogeneity can be expressed as the variability in hydraulic velocity and depth values (Statzner et al., 1988; Aadland, 1993; Jowett, 1993; Kemp et al, 1999; Schweizer et al., 2007). However, fish do not select physical variables independently; instead, distinct combinations of depth and velocity values that describe functional habitats, also known as mesohabitats, are a better measure of preferred habitat. These mesohabitats are also defined according to specific hydraulic 
variables such as the Froude number (Orth \& Maughan, 1983; Jowett, 1993; Kemp et al., 2000) and the velocity/depth ratio (Allan, 1995; Kemp et al., 1999; Brooks et al., 2005). Two-dimensional habitat simulation modelling is currently used in river restoration studies (Vehanen et al., 2003; Lacey \& Millar, 2004; Pasternack et al., 2004; Jalón \& Gortázar, 2007) because it is a powerful tool to explain the velocity and depth patterns in stream reaches (Leclerc et al., 1995; Ghanem et al., 1996; Crowder \& Diplas, 2000). When coupled with a biological model of habitat selection (Bovee, 1982), representing the preferences of different aquatic species for various instream habitat variables at different life history stages, the approach is even more powerful.

Depth and velocity values, combined with substrate composition, are usually considered the basic physical stream attributes that determine fish distribution (Parasiewicz \& Walker, 2007) and thus are commonly used in fish habitat models. The presence of refuge cover is much less used in modelling habitat availability, despite its potential importance in defining the distribution of individuals in a natural stream. Refuge cover comprises those instream areas where fish can hide from predators or rest, and it is normally composed of large roughness elements. Refuge cover can be a critical component of fish habitat that reflects the complexity of the river (Smith \& Brannon, 2007). Other instream characteristics that may be considered refuge cover include woody debris, overhanging vegetation and aquatic vegetation (Smith \& Brannon, 2007; Ayllón et al., 2008), as well as alteration of the appearance of the water surface due to turbulence (Bain \& Stevenson, 1999). Disregarding the importance of refuge cover in river restoration projects can lead to misinterpretation of the results of habitat modelling.

In this study, two-dimensional habitat simulations were used to compare habitat suitability scenarios for two native cyprinid fish species at three life stages. These simulations used different morphological variables along with reference to a minimally disturbed site located upstream for 'benchmarking' purposes. Specifically, we investigated the effect of using substrate and refuge

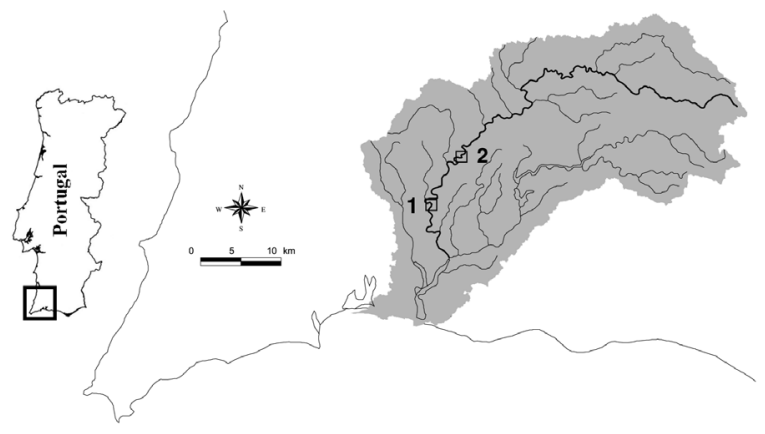

Figure 1. Location of the disturbed (1) and undisturbed (2) sites in the Arade Basin, Algarve, Portugal. Localización de la estación alterada (1) y no alterada (2) en la cuenca de Arade. Algarve, Portugal.

cover as morphological variables in combination with hydraulic parameters in modelling the original ecological situation.

\section{MATERIAL AND METHODS}

\section{Study area}

The study area is located in the Odelouca River, the largest tributary of the Arade basin $\left(987 \mathrm{~km}^{2}\right)$, in southwestern Iberia (Fig. 1). The Odelouca River is $92 \mathrm{~km}$ long and is dominated by schistose rocks, which are covered with alluvial deposits in the lower reaches. The climate is Mediterranean, with large intra-annual variability. More than $80 \%$ of the precipitation falls between October and March, when the rivers are prone to spates. From July to September, many parts of the river are partly dry and are represented by a succession of pools, which are disconnected in the upstream reaches.

The upper and middle courses present welldeveloped riparian galleries dominated by $A l$ nus glutinosa, Salix salviifolia ssp. australis and Fraxinus angustifolia, and they are free of major human impacts such as urban and agricultural pollution, impoundment and angling. However, irrigation crops and citrus groves occupy most of the lower catchment area, replacing the natural Mediterranean scrubland and cork-oak woodland vegetation (Quercus suber). Impacts from these activities include diffuse nutrient enrich- 
ment, destruction and fragmentation of riparian woodlands, straightening of the river channels and water abstraction from instream pools.

Southwestern arched-mouth nase (Iberochondrostoma almacai) (hereafter 'nase') and Arade chub (Squalius aradensis) (hereafter 'chub') are typical native species of the basin (Santos \& Ferreira, 2008). Currently, both present reduced populations and are critically endangered (Cabral et al., 2006). Other species include European eel (Anguilla anguilla) and southern Iberian spinedloach (Cobitis paludica). Exotic species, such as pumpkinseed sunfish (Lepomis gibbosus) and gambusia (Gambusia holbrooki), are mainly confined to the disturbed river reaches downstream.

Two study sites, both fourth-order streams (Strahler, 1957), were selected in the lower course of the Odelouca River, at 59 and $66.5 \mathrm{~km}$ from the source, respectively. The former site has a high degree of naturalness and is being used as a benchmark for river restoration goals. The latter site represents a disturbed section where the natural Mediterranean scrubland has been occupied by extensive citrus groves. These activities have changed the hydromorphology of the river by decreasing habitat heterogeneity through destruction of the riparian corridor and bank reinforcement (Table 1). The undisturbed site is $74 \mathrm{mlong}$ and $33 \mathrm{~m}$ in bankfull width, with a mixed channel substrate dominated by gravel. It has luxuriant riparian vegetation along both banks and multiple habitat cover features including overhanging trees, submerged blocks and woody debris. Together, these provide shelter over 20 to $40 \%$ of the total habitat area, in which fish can find rest and hide. The downstream disturbed site is $286 \mathrm{~m}$ long, and its average bankfull width is $58 \mathrm{~m}$. It has unstable banks with almost no vegetation or sheltered areas (i.e., 0 to $20 \%$ cover). The river substrate is composed mainly of gravel embedded with silt.

\section{Data collection}

The topography of the riverbed was surveyed in March 2005 with a Nikon DTM310 Total Station in combination with a Global Positioning System unit (GPS; Ashtechy, model Pro Mark2). Overall, 1824 and 4129 spots were surveyed
Table 1. Physical characteristics of the study sites at a flow of $2 \mathrm{~m}^{3} / \mathrm{s}$. Mean values \pm SE are given for depth, velocity and Froude number. Dominant substrate and cover class are indicated followed by their percentages in parentheses. Características físicas de las estaciones estudiadas con un caudal de $2 \mathrm{~m}^{3} / \mathrm{s}$. Se dan los valores medios \pm ES para la profundidad, velocidad y número de Froude. Se indican el tipo de substrato dominante y de cobertura seguida de los porcentajes entre paréntesis.

\begin{tabular}{lcc}
\hline Study site & Undisturbed & Disturbed \\
\hline Total length (m) & 74.1 & 286.2 \\
Average width (m) & 33.1 & 58.3 \\
Altitude (m) & 46 & 10 \\
Depth (m) & $0.41 \pm 0.21$ & $0.25 \pm 0.14$ \\
Maximum depth (m) & 0.86 & 0.73 \\
Velocity (m/s) & $0.70 \pm 0.56$ & $0.41 \pm 0.23$ \\
Froude number & $0.35 \pm 0.34$ & $0.26 \pm 0.14$ \\
Dominant substrate & Gravel (49) & Gravel (84) \\
class (\%) & & $0-20 \%(84)$ \\
Dominant cover & $20-40 \%(89)$ & Absent \\
class (\%) & Continuous in both banks & \\
Bank vegetation & & \\
\hline
\end{tabular}

at the undisturbed and disturbed sites, respectively. Water velocity and depth were measured at a series of points along four cross-sections at each site, located in different mesohabitats. Depths were measured with a meter ruler. Water velocities were measured with a water flow probe (model FP101, Global Water Instrumentation, USA) positioned at points below the upper $60 \%$ of the local flow depth (Bovee \& Milhous, 1978). The collected data were also used to calibrate bed roughness in the model and to establish the boundary conditions, specifically the water surface elevation at the downstream and upstream cross-sections. Substrate composition was assessed at each spot and classified according to a modified Wentworth scale (Bovee, 1986; silt: $1-2 \mathrm{~mm}$; sand: $2-5 \mathrm{~mm}$; gravel: $5-50 \mathrm{~mm}$; cobble: $50-150 \mathrm{~mm}$; boulder: > $150 \mathrm{~mm}$; bedrock). Refuge cover was defined as (i) any submerged structure (other than substrate) in which fish could be hidden from overhead view, (ii) undercut banks or overhanging vegetation $<0.5 \mathrm{~m}$ above the water surface and (iii) water surface turbulence. The percentage of refuge cover in the riverbed was visually assessed in $20 \%$ increments, from 0 to $100 \%$.

Habitat Suitability Curves (HSC) of depth, velocity, substrate and cover were developed for 
specific fish size-classes for nase $(<5,5-7$ and $>7 \mathrm{~cm})$ and for chub $(<4,4-6,>6 \mathrm{~cm})$ (Santos $\&$ Ferreira, 2008). These classes roughly correspond to the fish life-history stages of young-ofyear (YOY, $0+$ ), juveniles (1+) and adults (>1+), respectively (Magalhães et al., 2002). Sampling took place at undisturbed or minimally disturbed sites of the Odelouca basin so that habitat associations reflected the situation in optimal species habitat rather than an externally imposed displacement towards sub-optimal habitat (Gorman \& Karr, 1978). Fish were sampled during the flowing season, i.e., late May-early June 2005, when habitats were fully connected and fish were therefore not confined to pool habitats. Further details about site locations, sampling procedures and microhabitat measurements are given in Santos \& Ferreira (2008).

\section{Data analyses}

Simulations were carried out using River2D (Steffler, 2000) for a range of discharges from 0.3 to $12 \mathrm{~m}^{3} / \mathrm{s}$, representing the range expected during the natural flow regime in the reaches. The two-dimensional model was developed specifically for use in natural streams and rivers. The model creates a finite element mesh composed
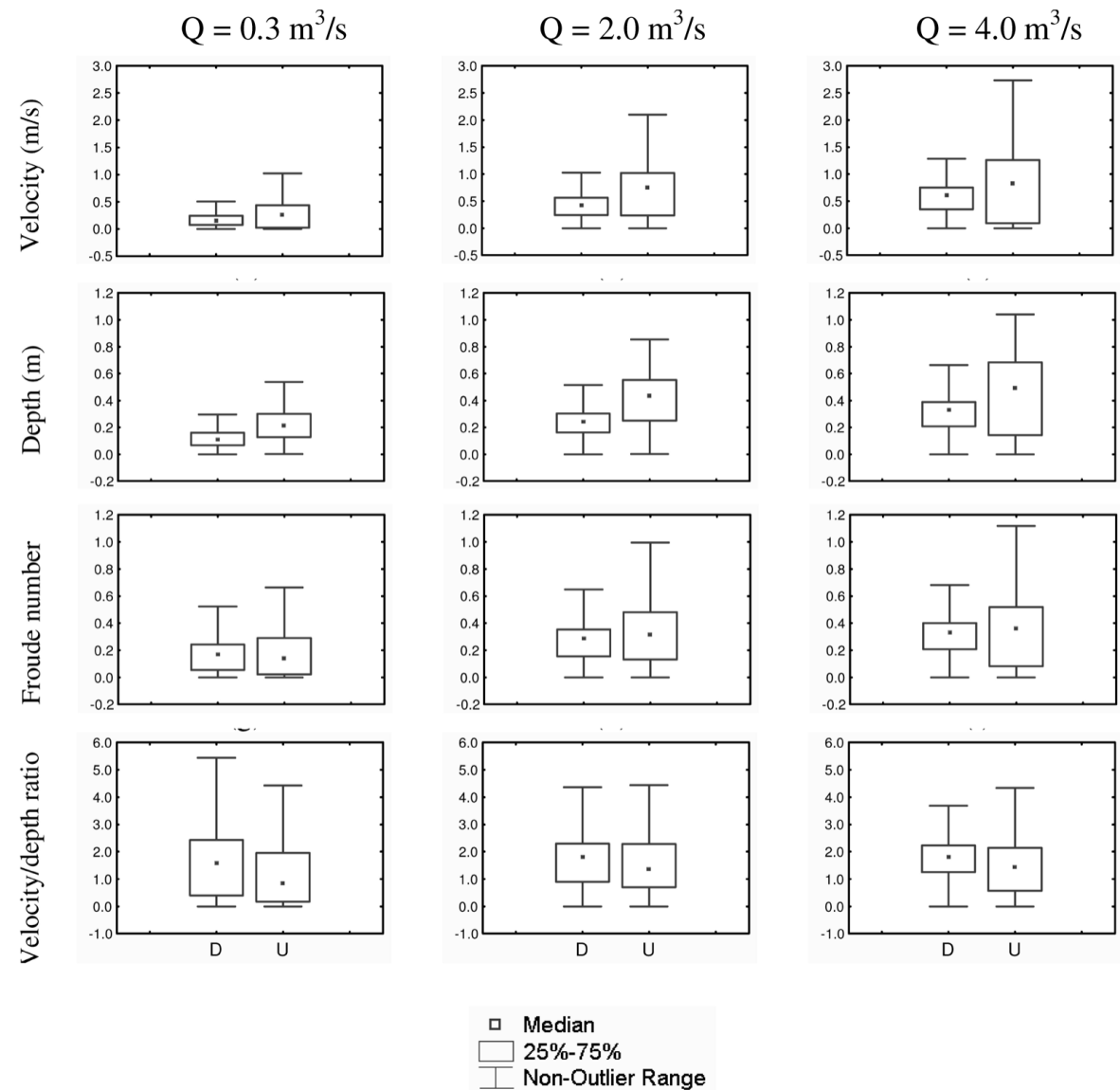

Figure 2. Water velocity $(\mathrm{m} / \mathrm{s})$, depth $(\mathrm{m})$, Froude number and velocity/depth ratio variability at different discharges $\left(0.3 \mathrm{~m}^{3} / \mathrm{s}\right.$, $2.0 \mathrm{~m}^{3} / \mathrm{s}$ and $4.0 \mathrm{~m}^{3} / \mathrm{s}$ ) at the undisturbed and disturbed sites in the Odelouca River, Arade Basin. The medians (central point), quartiles (box) and non-outlier range (whiskers) are shown in the plots. Velocidad del agua $(\mathrm{m} / \mathrm{s})$. profundidad ( $\mathrm{m}$ ), número de Froude y variación de la relación velocidad/profundidad para diferentes caudales $\left(0.3 \mathrm{~m}^{3} / \mathrm{s}, 2.0 \mathrm{~m}^{3} / \mathrm{s} \mathrm{y} 4.0 \mathrm{~m}^{3} / \mathrm{s}\right)$ en la estación alterada y no alterada en el río Odelouca, Cuenca de Arade. En las figuras se muestran, las medianas (punto central), cuartiles (Caja) y rango sin valores atípicos (whiskers). 
of triangular polygons of varying shapes and sizes. In each node, the hydraulic conditions (average depth and mean water velocity) are simulated, and the potential value of stream habitat (Weighted Useable Area; WUA) for the requirements of each species at each life stage is estimated. The hydraulic parameters (velocity, depth, Froude Number and velocity/depth ratio) and morphological parameters (substrate and refuge cover) at each node were plotted in box plots and used to compare the magnitude of differences (effect size) between sites. The model was calibrated by varying the effective roughness height and comparing the simulated and measured water surface elevations, and water velocity profiles along the four cross-sections where measurements were made. The quantity of area suitable for habitat (WUA) was calculated as the product of depth, velocity and morphological variable (i.e., substrate or refuge cover) (Bovee, 1986). To compare the habitat availability between sites, the WUA determined for each discharge was expressed as a percentage of the corresponding total wetted area, measured in the XY plane using ArcGIS 9.1.

\section{RESULTS}

\section{Physical characteristics of the study sites}

Differences between the first and third quartile values of velocity, depth and Froude number were larger for the undisturbed site compared with the disturbed site, independently of the discharge. However, variability of the velocity/depth ratio decreased with increasing discharge (Fig. 2). At each site, variability in velocity, depth and Froude number increased with discharge. As expected for all variables, the minimum values were always close to zero, and the maximum values increased with discharge. Moreover, velocity and depth at the undisturbed site had higher median values in all cases than at the disturbed site. For the Froude number and the velocity/depth ratio, the opposite trend was detected.

Substrate composition and refuge cover heterogeneity (number of classes observed) were
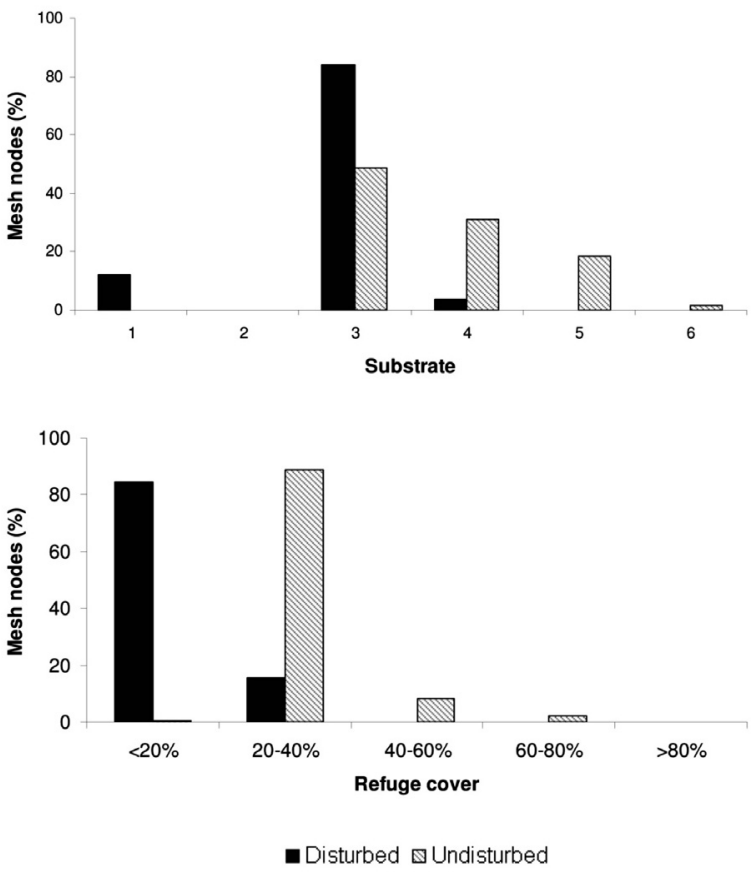

Figure 3. Substrate composition (see Material and Methods for codes) and percentage of refuge cover recorded at a discharge of $2.0 \mathrm{~m}^{3} / \mathrm{s}$ at the undisturbed and disturbed sites in the Odelouca River, Arade Basin. Composición del substrato (ver Material y Métodos para los códigos) y tanto por ciento de cobertura de refugio medido a un caudal de $2.0 \mathrm{~m}^{3} / \mathrm{s}$ en la estación alterada y no alterada en el río Odelouca, cuenca del Arade.

higher at the undisturbed site (Fig. 3). The dominant substrate class for both sites was gravel, which completely dominated the disturbed site (84\% of spot observations) but was present at a lower proportion at the undisturbed site. Approximately $90 \%$ of the observed spots at the undisturbed site had 20-40\% cover, whereas $0-20 \%$ cover was observed in $84 \%$ of the spots at the disturbed site.

\section{Habitat availability and use}

When substrate was used as the morphological variable, higher habitat availability at lower discharges for the undisturbed site was predicted for all nase and chub life stages except for adult chub, and especially for YOY (Figs. 4 and 5). For higher discharges (i.e., $>6 \mathrm{~m}^{3} / \mathrm{s}$ ) there was a trend towards increased usable area at the undis- 
turbed site compared to the disturbed site. However, when refuge cover was used as the morphological variable, higher WUA values were predicted for the undisturbed site across almost the entire flow range for all nase and chub life stages, with the exception of YOY chub, for which higher WUA values were found at the disturbed site for lower discharges $\left(\mathrm{Q}<7 \mathrm{~m}^{3} / \mathrm{s}\right)$.
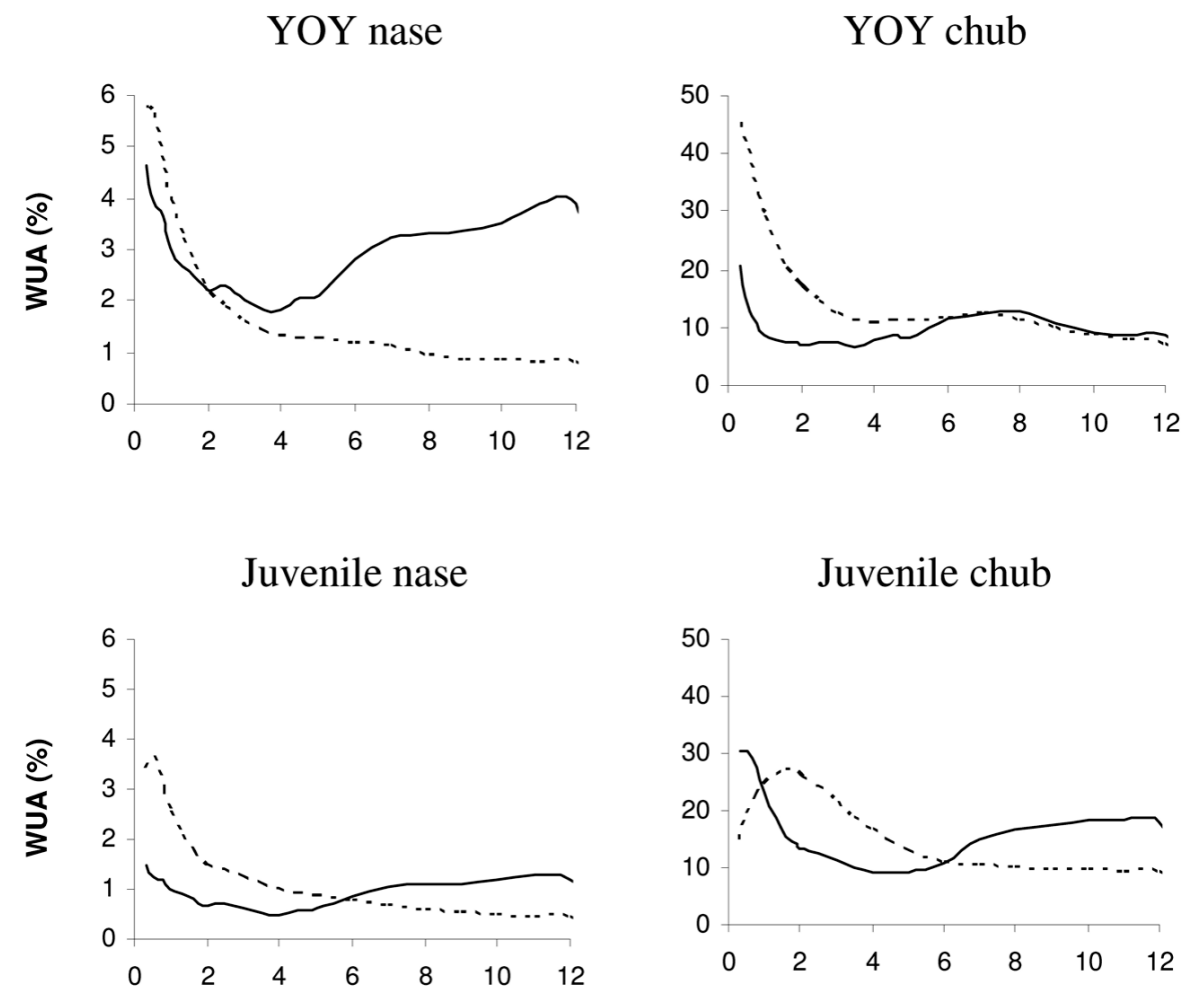

Juvenile chub

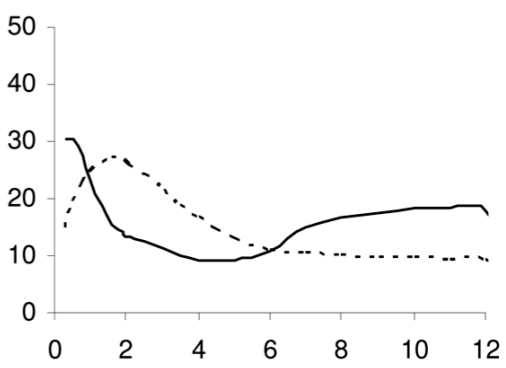

Adult nase

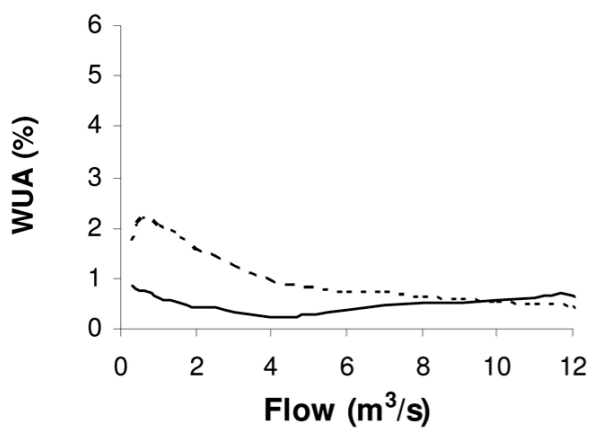

Adult chub

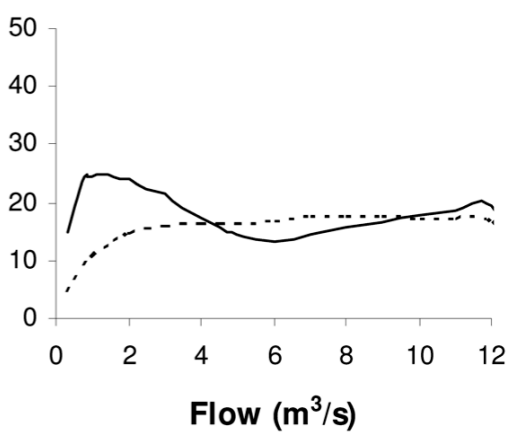

Undisturbed

Figure 4. Weighted Usable Area (WUA) percentages across different flow discharges considering substrate composition as the morphological variable at the undisturbed and disturbed sites in the Odelouca River, Arade Basin. Tanto por ciento de Área Utilizable Ponderada (WUA) para diferentes caudales considerando la composición del substrato como variable morfológica en la estación alterada y no alterada en el río Odelouca, cuenca de Arade. 


\section{DISCUSSION}

A two-dimensional modelling approach was applied to predict the habitat availability for two endangered cyprinid species by considering, al-
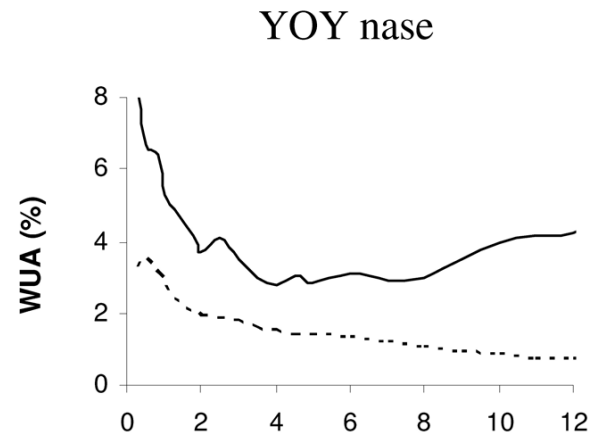

Juvenile nase

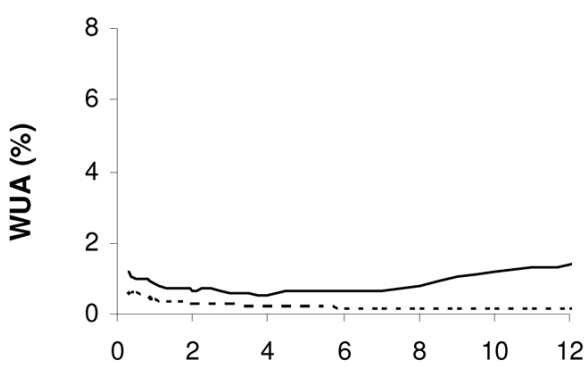

Adult nase

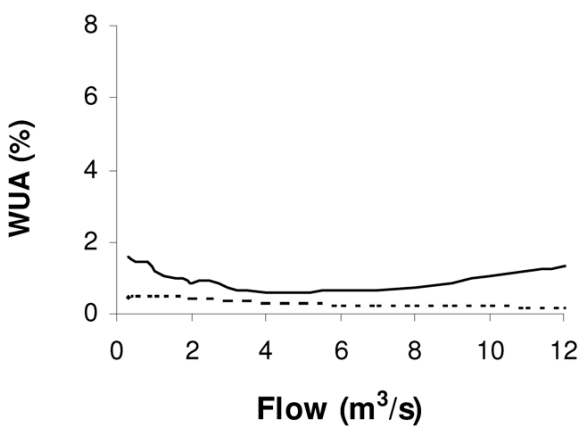

ternately, substrate or refuge cover as the morphological variable in a WUA formulation (i.e., product of depth, velocity and substrate or cover) at undisturbed and disturbed sites.

A natural stream usually has a complex habi-
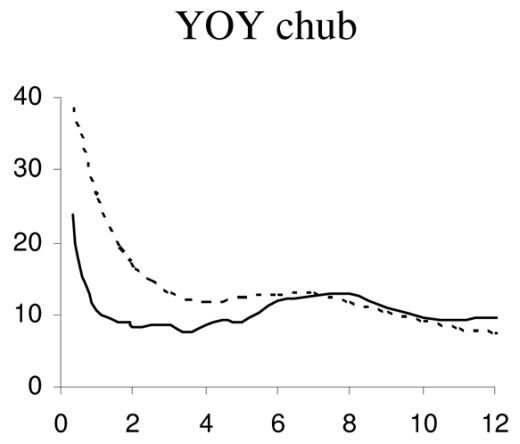

Juvenile chub

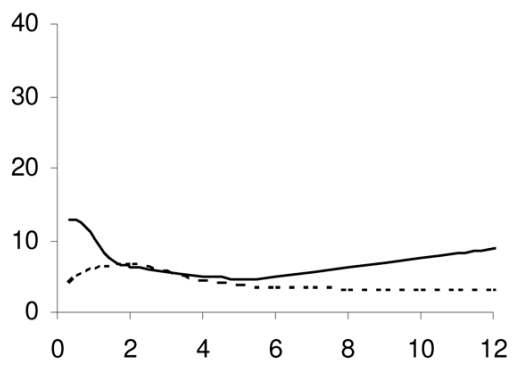

Adult chub

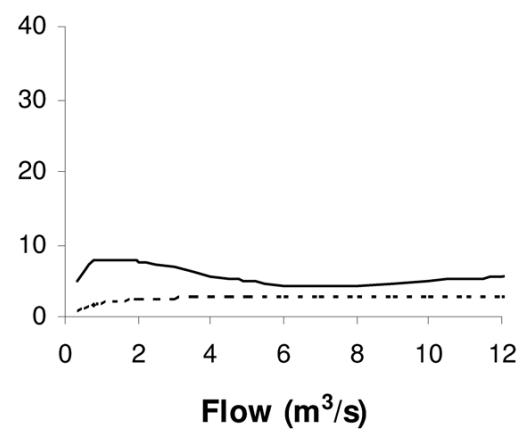

Undisturbed

Figure 5. Weighted Usable Area (WUA) percentages across different flow discharges considering refuge cover as the morphological variable at the undisturbed and disturbed sites in the Odelouca River, Arade Basin. Tanto por ciento de Área Utilizable Ponderada (WUA) para diferentes caudales considerando la cobertura de refugio como variable morfológica en la estación alterada y no alterada en el río Odelouca, cuenca de Arade. 
tat structure, enabling fish assemblage persistence (Palmer et al., 1997; Kemp et al., 1999; Eros, 2007). Undisturbed aquatic ecosystems should have a habitat matrix (e.g., rearing and spawning habitat, feeding areas and refuges, lower and deeper zones as well as high current velocity and static water) that is able to support all life stages of all species. In this study, we found higher spatial heterogeneity at the undisturbed site, independently of discharge, for depth, velocity and Froude number. Though freshwater fishes are usually strongly influenced by depth and velocity patterns (Jowett, 1993; Kemp et al., 2000; Schweizer et al., 2007), other variables such as substrate and refuge cover can be equally important (Smith \& Brannon, 2007; Ayllón et al., 2008). In addition, chemical and biotic factors (e.g., food availability and the presence of competitors) can be of greater importance at very low flow conditions (Pires et al., 2000), and their inclusion in habitat modelling should be considered in future studies.

The results of the present study show not only the importance of morphological variables in assessing habitat availability but also the importance of selecting one particular variable over another. In general, when substrate was used as the morphological variable in the WUA assessment, the habitat availability for both species was higher in the disturbed site compared with the undisturbed site. The results were different when refuge cover was considered as the morphological variable, i.e., habitat availability for both species at the undisturbed site was higher than at the disturbed site. Because the relationships between habitat preferences of certain species and particular hydraulic conditions are well known (Aadland, 1993; Mérigoux \& Dolédec, 2004), river restoration is generally focused on enhancement of hydraulic variability as a surrogate for fish habitat use. However, other variables also play an important role in determining fish distribution. The habitat simulations carried out in this study underline the importance of considering refuge cover in fish habitat modelling studies (Smith \& Brannon, 2007; Ayllón et al., 2008). However, fish preferences for specific cover type are not known (Vehanen et al., 2000). When sub- strate was considered as the morphological variable at the undisturbed site, results revealed lower habitat availability at lower discharges, in spite of the higher heterogeneity at this site. Therefore, not taking refuge cover into account in habitat simulation studies may lead to incorrect conclusions.

Before a river restoration project takes place, it is important to consider the hydraulic variables as well as the biotic factors that may play an important role in species distribution. To know which variables should be considered in river restoration projects, one needs to assess the importance of hydraulic and biotic features at undisturbed sites of the same river. This has been stated in the reference approach that guides river restoration actions (Choi, 2004; Palmer et al., 2004; Woolsey et al., 2007). In our investigation, habitat complexity at the undisturbed site was better explained using refuge cover to determine the amount of habitat available for nase and chub. Due to the simplicity of characterising the substrate, this variable has been widely used in river restoration projects. So far, this is a fundamental aspect of river restoration that has usually been neglected.

Habitat models that simulate complex flow patterns in streams resulting from the interaction of physical variables and flow, such as the one applied in this study, have proved to be useful tools to describe the hydraulics in streams (Leclerc et al., 1995; Crowder \& Diplas, 2000). Currently, 2D habitat models involving WUA determination are confined to the use of one morphological variable, unless several morphological variables are combined into a single value, which will have dubious ecological relevance. Because of the complexity of natural systems, there will always be important features that are ignored in models. Nonetheless, this study highlights the importance of refuge cover in the determination of the WUA for different fish species and life stages and therefore supports the idea that refuge cover is a habitat characteristic that should be taken into account.

\section{ACKNOWLEDGEMENTS}

The authors would like to thank Rui Cortes and José Lourenço for supplying the topographic 
data as well as Paulo Pinheiro for his help in drawing the study area map. Thanks are also due to two anonymous reviewers who provided useful comments on an early draft of this paper. Isabel Boavida was supported by a grant (SFRH/BD/35801/2007) from FCT (Portuguese Science and Technology Foundation).

\section{REFERENCES}

AADLAND, L. P. 1993. Stream Habitat Types: Their Fish Assemblages and Relationship to Flow. North American Journal of Fisheries Management, 13: 790-806.

ALLAN, J. D. 1995. Stream Ecology: Structure and Function of Running Waters. Chapman \& Hall: London. 436 pp.

AYLLÓN, D., A. ALMODÓVAR, G. G. NICOLA, B. ELVIRA. 2008. Interactive effects of cover and hydraulics on brown trout habitat selection patterns. River Research and Applications, 25: 1051-1065.

BAIN, M. B.\& N. J. STEVENSON. 1999. Aquatic Habitat Assessment. American Fisheries Society. Bethesda. Maryland. 216 pp.

BOVEE, K. D. 1982. A guide to stream habitat analysis using the Instream Flow Incremental Methodology. Instream Flow Information Paper No. 12. USDA Fish and Wildlife Service, Office of Biological Services. FWS/OBS-82/26.

BOVEE, K. D. 1986. Development and evaluation of habitat suitability criteria for use in the instream flow incremental methodology. Fort Collins, CO, U.S. Fish and Wildlife Service Biological Report 86 (7).

BOVEE, K. D. \& R. T. MILHOUS. 1978. Hydraulic simulation in instream flow studies: theory and technique. Instream Flow Paper No. 5, U. S. Fish and Wildlife Service/Office of Biological Services-78/33.

BROOKS, A. J., T. HAEUSLER, I. REINFELDS \& S. WILLIAMS. 2005. Hydraulic microhabitats and the distribution of macroinvertebrate assemblages in riffles. Freshwater Biology, 50: 331-344.

CABRAL, M. J., J. ALMEIDA, P. R. ALMEIDA, T. DELLINGER, N. FERRAND de ALMEIDA, M. E. OLIVEIRA, J. M. PALMEIRIM, A. L. QUEIROZ, L. ROGADO \& M. SANTOS-REIS. 2006. Livro Vermelho dos Vertebrados de Portugal, Instituto da Conservação da Natureza, Assírio \& Alvim, Lisbon. 219 pp.
CHOI, Y. D. 2004. Theories for ecological restoration in changing environment: towards 'futuristic' restoration. Ecological Research, 19: 75-81.

COLWELL, R. K. \& D. J. FUTUYMA. 1971. On the measurement of the niche breadth and overlap. Ecology, 52: 567-576.

CROWDER, D. W. \& P. DIPLAS. 2000. Using twodimensional hydrodynamic models at scales of ecological importance. Journal of Hydrology, 230: 172-191.

EROS, T. 2007. Partionating the diversity of riverine fish: the roles of habitat types and non-native species. Freshwater Biology, 52: 1400-1415.

GHANEM, A., P. STEFFLER \& F. HICKS. 1996. Two dimensional hydraulic simulation of physical habitat conditions in flowing streams. Regulated Rivers: Research and Management, 12: 185-200.

GLEICK, P. H. 2003. Global freshwater resources: soft-path solutions for the 21 st century. Science, 302: 1524-1528.

GORMAN, O. T. \& J. R. KARR. 1978. Habitat structure and stream fish communities. Ecology, 59: 507-515.

HARPER, D., M. EBRAHIMNEZHAD \& F. C. COT. 1998. Artificial riffles in river rehabilitation: setting the goals and measuring the successes. Aquatic Conservation: Marine and Freshwater Ecosystems, 8: 5-16.

HARRISON, S. S. C., J. L. PRETTY, D. SHEPHERD, A. G. HILDREW, C. SMITH, R. D. HEY. 2004. The effect of instream rehabilitation structures on macroinvertebrates in lowland rivers. Journal of Applied Ecology, 41: 1140-1154.

HENRY, C. P., C. AMOROS \& N. ROSET. 2002. Restoration ecology of riverine wetlands: a 5 year post-operation survey on the Rhône River, France. Ecological Engineering, 18: 543-554.

JALÓN, D. G. \& J. GORTÁZAR. 2007. Evaluation of instream habitat enhancement options using fish habitat simulations: case-studies in the river Pas (Spain). Aquatic Ecology, 41: 461-474.

JOWETT, I. G. 1993. A method for objectively identifying pool, run, and riffle habitats from physical measurements. New Zealand Journal of Marine and Freshwater Research, 27: 241-248.

JUNGWIRTH, M., S. MUHAR \& S. SCHMUTZ. 1995. The effects of recreated instream and ecotone structures on the fish fauna of an epipotamal river. Hydrobiology, 303: 195-206. 
KEMP, J. L., D. M. HARPER \& G. A. CROSA. 1999. Use of 'functional habitats' to link ecology with morphology and hydrology in river rehabilitation. Aquatic Conservation: Marine and Freshwater Ecosystems, 9: 159-178.

KEMP, J. L., D. M. HARPER \& G. A. CROSA. 2000. The habitat-scale ecohydraulics of rivers. Ecological Engineering, 16: 17-29.

KONDOLF, G. M. \& E. R. MICHELI. 1995. Evaluating stream restoration projects. Environment Management, 19: 1-15.

LACEY, R. W. \& J. R. MILLAR. 2004. Reach scale hydraulic assessment of instream salmonid habitat restoration. Journal of the American Water Resources Association, 40: 1631-1644.

LECLERC, M., A. BOUDREAULT, J. A. BECHARA, G. CORFA. 1995. Two-Dimensional Hydrodynamic Modeling: A Neglected Tool in the Instream Flow Incremental Methodology. Transactions of the American Fisheries Society, 124: 645662.

MAGALHÃES, M. F., P. BEJA, C. CANAS, M. J. COLLARES-PEREIRA. 2002. Functional heterogeneity of dry-season fish refugia across a Mediterranean catchment: the role of habitat and predation. Freshwater Biology, 47: 1919-1934.

MÉRIGOUX, S. \& S. DOLÉDEC. 2004. Hydraulic requirements of stream communities: a case study on invertebrates. Freshwater Biology, 49: 600613.

MONTGOMERY, D. R. 1997. What's best on the banks. Nature, 388: 328-329.

NAIMAN, R. J. \& M. G. TURNER. 2000. A future perspective on North America's freshwater ecosystems. Ecological Applications, 10: 958-970.

ORTH, D. J. \& O. E. MAUGHAN. 1983. Microhabitat preferences of benthic fauna in a woodland stream. Hydrobiologia, 106: 157-168.

PALMER, M. A., R. F. AMBROSE \& N. L. POFF. 1997. Ecological theory and community restoration ecology. Restoration Ecology, 5: 291-300.

PALMER, M. A., E. BERNHARDT, E. CHORNESKY, S. COLLINS, A. DOBSON, C. DUKE, B. GOLD, R. JACOBSON, S. KINGSLAND, R. KRANZ, M. MAPPIN, M.L. MARTINEZ, F. MICHELI, J. MORSE, M. PACE, M. PASCUAL, S. PALUMBI, O. J. REICHMAN, A. SIMONS, A. TOWNSEND \& M. TURNER. 2004. Ecology for a crowded planet. Science, 304: 1251-1252.

PALMER, M. A., E. S. BERNHARDT, J. D. ALLAN, P. S. LAKE, G. ALEXANDER, S. BROOKS, J.
CARR, S. CLAYTON, C. N. DAHM, J. FOLLSTAD SHAH, D. L. GALAT, S. G. LOSS, P. GOODWIN, D. D. HART, B. HASSETT, R. JENKINSON, G. M. KONDOLF, R. LAVE, J. L. MEYER, T. K. O'DONNELL, L. PAGANO \& E. SUDDUTH. 2005. Standards for ecologically successful river restoration. Journal of Applied Ecology, 42: 208-217.

PARASIEWICZ, P. \& J. D. WALKER. 2007. Comparison of MesoHABSIM with two microhabitat models (PHABSIM and HARPHA). River Research and Applications, 23: 904-923.

PASTERNACK, G. B., C. L. WANG \& J. E. MERZ. 2004. Application of a 2D hydrodynamic model to design of reach-scale spawning gravel replenishment on the Mokelumne River, California. River Research Application, 20: 205-225.

PETTS, G. E., J. G. IMHOF, B. A. MANNY, J. F. B. MAHER \& S. B. WEISBERG. 1989. Management of fish populations in large rivers: a review of tools and approaches. In: Proceedings of the International Large River Symposium. D. P. Dodge (ed.): pp. 578-588. Canadian Special Publication of Fisheries and Aquatic Sciences, 106. NRC Research Press, Ottawa, Canada.

PIRES, A. M., I. G. COWX \& M. M. COELHO. 2000. Life history strategy of Leuciscus pyrenaicus (Cyprinidae) in intermittent streams of the Guadiana basin (Portugal). Cybium, 24: 287-297.

PRETTY, J. L., S. S. C. HARRISON, D. J. SHEPHERD, C. SMITH, A. G. HILDREW \& R. D. HEY. 2003. River rehabilitation and fish populations: assessing the benefit of instream structures. Journal of Applied Ecology, 40: 251-265.

RHEINHARDT, R. D., M. C. RHEINHARDT, M. M. BRINSON \& K. E. FRASER. 1999. Application of reference data for assessing and restoring headwater ecosystems. Restoration Ecology, 7: 241251.

RONI, P. \& FAO-ONU. 2005. Habitat rehabilitation for inland fisheries: global review of effectiveness and guidance for rehabilitation of freshwater ecosystems. Food and Agriculture Organization of the United Nations, Rome. 116 pp.

SALA, O. E., F. S. CHAPIN, J. J. ARMESTO, E. BERLOW, J. BLOOMFIELD, R. DIRZO, E. HUBER-SANWALD, L. F. HUENNEKE, R. B. JACKSON, A. KINZIG, R. LEEMANS, D. M. LODGE, H. A. MOONEY, M. OESTERHELD, N. L. POFF, M. T. SYKES, B. H. WALKER, M. 
WALKER \& D. H. WALL. 2000. Global biodiversity scenarios for the year 2100. Science, 287: 1770-1774.

SANTOS, J. M. \& M. T. FERREIRA. 2008. Microhabitat use by endangered Iberian cyprinids nase Iberochondrostoma almacai and chub Squalius aradensis. Aquatic Science, 70: 272-281.

SCHWEIZER, S., M. E. BORSUK, I. JOWETT \& P. REICHERT. 2007. Predicting joint frequency distributions of depth and velocity for instream habitat assessment. River Research and Applications, 23: 287-302.

SMITH, D. L. \& E. L. BRANNON. 2007. Influence of cover on mean column hydraulic characteristics in small pool riffle morphology streams. River Research and Applications, 23: 125-139.

STATZNER, B., J. A. GORE \& V. H. RESH. 1988. Hydraulic stream ecology: observed patterns and potential applications. Journal of the North American Benthological Society, 7: 307-360.

STEFFLER, P. 2000. Software River2D. Two Dimensional Depth Averaged Finite Element Hydrodynamic Model, University of Alberta, Canada.

STRAHLER, A. N. 1957. Quantitative analysis of watershed geomorphology. Transactions of the American Geophysical Union, 38: 913-920.

STRANGE, R. M. 1999. Historical biogeography, ecology, and fish distributions: conceptual issues for establishing IBI criteria. In: Assessing the Sustainability and Biological Integrity of Water Resources Using Fish Communities. T. P. Simon(ed.): 65-78. CRC Press, Boca Raton, Florida, USA.
SUDING, K. N., K. L. GROSS \& D. R. HOUSMAN. 2004. Alternative states and positive feedbacks in restoration ecology. Trends in Ecology and Evolution, 19: 46-53.

VEHANEN, T., P. L. BJERKE, J. HEGGENS, A. HUUSKO \& A. MÄKI-PETÄYS. 2000. Effect of fluctuating flow and temperature on cover type selection and behaviour by juvenile brown trout in artificial steams. Journal of Fish Biology, 56: $923-$ 937.

VEHANEN, T., A. HUUSKO, T. YRJÄNÄ, M. LAHTI \& A. MÄKI-PETÄYS. 2003. Habitat preference by grayling (Thymallus thymallus) in an artificially modified, hydropeaking riverbed: a contribution to understand the effectiveness of habitat enhancement measures. Journal of Applied Ichtyology, 19: 15-20.

WESCHE, T. A. 1985. Stream channel modifications and reclamation structures to enhance fish habitat. In: The Restoration of Rivers and Streams J. A. Gore(ed.): 103-159. Butterworth, Boston.

WHEATON, J. M., G. B. PASTERNACK \& J. E. MERZ. 2004. Spawning habitat rehabilitation-II. Using hypothesis development and testing in design, Mokelumne River, California, USA. International Journal River Basin Management, 2: 21-37.

WOOLSEY, S., F. CAPELLI, T. GONSER, E. HOEHN, M. HOSTMANN, B. JUNKER, A. PAETZOLD, C. ROULIER, S. SCHWEIZER, S. D. TIEGS, K. TOCKNER, C. WEBER \& A. PETER. 2007. A strategy to assess river restoration success. Freshwater Biology, 52: 752-769. 